Новица Ж. Милић*

Универзитет Сингидунум, Београд, Факултет за медије и комуникације

\title{
ДОН КИХОТ И КњИЖЕВНост
}

Овај рад се ослања на предавања које је аутор држао низ година студентима Катедре за општу књижевност између 2001. и 2008. године, на истом месту на којем је имао част да четврт столећа раније слуша излагања проф. Александра Илића о европској ренесансној књижевности. Рад представља поглед на Сервантесов роман Дон Кихот из угла рађања модерног романа - жанра који је постојао и пре, али који тек са модерним иронијским, историјским и поетичким искуством ренесансног доба постаје оно што ће бити у наредним вековима - вероватно најшире прихваћен и најчешћи облик истраживања света и живота. Иронију овај Сервантесов роман успоставља у дистанци и према себи, свом јунаку, начинима приповедања, и према ранијој књижевности - не само према тзв. витешким романима и пикарским приповестима, већ и према литератури и култури ранијег, средњовековног времена. Из историјског угла, роман алудира на прошлост колико и савременост или понекад непосредно обрађује колико једну толико и другу, а поетички обухвата и друге раније жанрове, попут пасторале и фантастике наслеђене из грчко-римске антике. Нарочито се у раду обраћа пажња на однос два дела романа, првог из 1605. и другог из 1615. године, кад се, у другом делу, мења приповедачка перспектива: јунак Дон Кихот остаје и пустолов и велики читалац раније витешке књижевности, али сада и јунак о којем постоје чак два романа: Сервантесов први део и кривотворени „наставак“ извесног Авељанеде, који су други ликови у Сервантесовом роману читали, чиме се добија нека врста металитерарног књижевног плана. Надаље, више није проблематика само она развијена у првом делу - како један лик чита свет сходно штиву раније, витешке литературе - већ се сада развија и тема нечитљивости, не само „погрешног разумевања“ света као раније, већ начелне нечитљивости властите судбине и места у свету, а тиме и тема скривене нечитљивости књижевног дела, одакле се рађа и феномен тзв. вишезначности песништва. То се види нарочито ако се Сервантесова поетика упореди са каснијим поетикама, у овом случају са Борхесовом из приче о Пјеру Менару.

Кључне речи: Сервантес, Дон Кихот, ренесансна књижевност, модерни роман, иронија, читљивост, нечитљивост, Борхес.

Средином лета друге половине или при крају XVI века један мршави, издужени педесетогодишњак, који је своје име Кезада, Кихада, или, вероватније, Кихано донекле променио у Дон Кихот (Кихоте) од Манче, увучен у зарђали оклоп и са нечим на глави што би требало да је шлем, наоружан копљем и штитом, у рано јутро, пре дана, на свом коњу полази да тражи пустоловине. Зашто? Како би витешки и племенито исправљао неправде по свету, притицао у помоћ невољницима, спасавао угрожене. Могла би то

novica.milic@fmk.edu.rs 
бити devotio moderna, о којој је много раније већ говорио Еразмо Ротердамски, „модерно посвећење“ хришћанским и људским идеалима праведности и спасења, што би била дужност образованог човека у новом времену; та ће Еразмова замисао имати великог одјека у Шпанији XVI столећа, мада ће бити извор забуна и застрањења, понекад и јереси или барем сумњи у јерес њених присталица, званих и „еразмисти“. Могао би, такође, бити и одговор на велике колонијалне подухвате које је предузела Шпанија у новооткривеном свету, у „Индијама“, то јест на америчким континентима, куд се кретало под званичним изговором ширења хришћанске вере, евангелизације пагана и ширења царства Божјег; манчански витез био би реплика на освајаче у име Светог писма. Историја, она културна и књижевна, била би тако у позадини Дон Кихотових намера. Али у ужем значењу, како видимо из извештаја о његовим пустоловинама, могла је то бити витешка литература, романсиране приповести које су цветале у латинским земљама, посебно у Шпанији, током истог тог столећа, попут оних о Амадису из Галије, или Амадису из Греције, у којима се храбри хришћански витез одриче грађанског живота и полази у борбу против снажнијих непријатеља, најчешће обликованих по митском обрасцу чудовишта или фигура из света бајки и народних предања - витез на тај начин обнавља замисао тзв. наоружаног хришћанства, односно мисију самог Христа који долази да спасе свет и успостави ново царство правде. Додуше, ово луталаштво посвећено спасењу, главна тема витешких романа, прозних наследника витешких спевова и романси, добиће пред крај овог раздобља својеврсну пародију у тзв. пикарском роману, у ком је јунак луталица, сада мангуп и преварант, који прича о свом животу у аутобиографској форми, и у којој тема скитничења пружа широко поље за сликање разних социјалних и културних слојева, попут Ласариља од Тормеса (1554) анонимног аутора, Гусмана од Алфараће Матеа Алемана, или Кеведовог Животописа лупежа. Појава пикарског романа већ наговештава да је претходни, витешки, на свом заласку; Сервантес ће свој роман о Дон Кихоту моћи да постави и као пародију витештва и витешких романа, и да у њега укључи поједине елементе пикарских повести, пре свега „поглед одоздо“ на свет живота и на поступке људи.

Али роман о Дон Кихоту биће много више од тога: означиће, својом појавом, рађање модерног романа као нове литерарне моћи, не само по облику, већ и као могућности да се средствима литературе истражују димензије света и постојања, историје и појединца, на начине на које дотле књижевност то није могла. Роман, чије почетке можемо трасирати све до старе египатске књижевности, преко античког романа било пасторалног типа 
(Лонгов Дафнид и Хлоја), било римске фантастичке сатире (Апулејев Златни магарац), преко трагова у средњовековним хагиографијама, а онда у напорима ренесансних приповедача да својим збиркама обезбеде целину преко тзв. оквирне приче (Бокачо, Чосер, Маргарита од Наваре), са Сервантесом заправо добија своје парадигматско дело за потоњу модерност. Та се парадигма на површини састоји од дуге приповести о једном или више главних јунака испричане кроз епизоде као видове развоја радње, заплета и расплета, пружајући један преглед света као отворености у коју се тај преглед смешта својим исечком. Иза илузије тоталитета који роман ствара, иза привида континуитета времена, простора, мотивације, заправо налазимо низове у којима се тај исти свет дискурсивно плурализује: роман зна за слободну употребу језика у разним регистрима, од високих, свечаних, узвишених, метафизички или пасторално усмерених, па све до нижих, свакодневних, колоквијалних; он у начелу допушта употребу различитих стилова, па и других мањих облика које може да употреби као своје сегменте, епизодно или локално се развијајући кроз њих; роман је отуда отворенија форма од многих других, хибридизација врста и родова, њихових техника и образаца. Роман такође рачуна на начелну плурализацију перспектива из којих или у којима представља (репрезентује) догађаје, на више нивоа уопштавања и/или конкретизације, на варијације и премештања становишта, углова из којих дискурсивни субјекти посматрају догађај у којем су учесници или су му сведоци; с тим је повезана и плурализација субјективности - роман има више тачака субјективације, увек је у њему више од једног лика, ликови су између себе у стању разлика доведених до одређених тензија, што отвара поље за заједничку драму; понекад плурализација субјективности иде и унутар једног лика, он се развија као однос, разлика или тензија према себи самом, као драма властитог карактера. Без плурализације истине, перспективизма и одређене релативизације сазнајне инстанце, што је све учинак ренесансног књижевног и мисаоног искуства, не би било ни романа као важног вида модерне свести и њеног самопреиспитивања.

Сервантес на више начина умножава своје перспективе. Чини то најпре плурализацијом наративних гласова. Ауторско „ја“, које се на почетку, у прологу, обраћа читаоцу:

Докони читаоче, и да ти се не кунем, можеш ми веровати да желим да ова књига, као чедо мога ума, буде најлепша, најумиљатија и најчеднија, како се само може замислити -

доста брзо заузима став дистанце („Али ја, који, ако и изгледам да сам отац Дон Кихоту, тек сам му поочим“), открива се, у 
деветом поглављу првог дела романа, као један, последњи у низу преносника повести коју је, давно пре њега, створио неко други. У тој глави, нагло прекинувши епизоду двобоја свог главног јунака са извесним Бискајцем, остављајући их да дословно чекају („са уздигнутим и голим мачевима, готове да зададу два љута ударца“) на наставак радње, ауторско „ја“, дотле изједначено са нараторским, окреће се питању саме приче и њеног извора. Сада нам приповеда како је на пијаци у Толеду налетео на

некаква дерана како продаје једном свилару неке тетраде и старе хартије: па како имам страст да читам, ако ће бити и хартије с улице, побуђен том мојом природном склоношћу узмем један свитак од оних што их је деран продавао и познам да је исписан арапским писменима. Али, иако сам то познао, нисам умео да читам, те се дигнем да нађем каквог пошпањоленог Мориска, да прочита.

Тај Мориско (Мавар, потомак Арапа који су, као и Јевреји, протерани из Шпаније крајем XV века), кога ће упослити да потом преведе откупљене хартије, каже му да наслов списа гласи: Повест о Дон Кихоту од Манче, списана Сидом Аметом Бенениелијом, арапским повесничарем. Тиме се супротставља ланац приповедача, преносника, аутора: Сид Амет Бененџелија, потом маварски преводилац, а тек на крају, као трећа рука, само ауторско „ја“. Ова конвенционална дистанца између приповедача, који се представља као приређивач и редактор нечијег туђег рукописа или историје, у исти мах чува сећање на ситуацију у којој се налазио класичан, антички аутор, онај ко је само „приређивао“, што значи изабирао, распоређивао и донекле подешавао митолошку ризницу прича и ликова за потребе своје публике, али ту ситуацију и мења, утолико што поименице уводи различите преноснике и повећава размак између њих. Он тиме отвара већи простор за наративне маневре, шири волумен приповедног поља, омогућава поигравање конвенцијама и превредновање самог система уверљивости и вероватноће - тако ће ауторско „ја“ моћи да се огради, у случајевима кад то захтева одређени ефекат, од првобитног приповедача, бацајући на овог потоњег одговорност за одређене неусаглашености или амбиваленције. Тим пре што ће се за Сид Амета Бененџелију казати и да је „писац Арапин, а том је народу својствено да лаже“, као што ће се на другом месту величати његова „мудрост и поштење“ („у свему врло савестан“, XVI гл.; „мудри и вредни“, XXVII гл.). Конвенција барем двоструког - у случају Сервантесовог текста и троструког - наратора могла је бити непосредно преузета из витешког романа 
(Амадис из Галије, најпознатији витешки роман који ће се често помињати у Дон Кихоту, такође се ослања на ову конвенцију, сходно којој је ауторска улога подељена између маварског хроничара и хришћанског редактора), и она ће остати важно својство модерног романа, често отворено наглашена у романима XVIII и XIX века, а биће својеврсна пародија нараторске позиције пикарског романа (који је са своје стране пародија витешког романа), у ком се, по правилу, изједначава нараторски глас и глас главног јунака у аутобиографској исповести.

Наиме, аутобиографија би се могла, сходно својој идентификацији приповедача и главног јунака, при којој се причање развија под плаштом сведочења или исповести, узети за саму слику уверљивости, веродостојности и самосвести: у њој би се свако представљање изједначавало са самотумачењем субјекта, па стога и затварало празан простор између наративне представе и реалног догађаја. Али то је само привидно тако. Барем два догађаја аутобиографски јунак не може испричати из угла сведока или исповести о себи - почетак, односно крај властитог живота. Ова парцијалност аутобиографског исказа заправо почива на начелној могућности да се о себи не говори дословна истина, већ да се јунак-приповедач преда измишљању, фабулацији. Сама нарација у начелу отвара простор за фикционализацију, то јест за разлику између гласа који приповеда и говора којим се приповеда или којим се говори о нечему другоме. Из поља те разлике може доћи до различитих обрта - Сервантес неће пропустити ту прилику у свом умножавању приповедачких гласова, као што неће пропустити прилику да укаже на амбиваленцију аутобиографског дискурса и, посебно, пикарске конвенције приповедања о себи. У XXII поглављу („О слободи коју је Дон Кихот дао многим несрећницима које су против њихове воље онамо водили куда нису марили да иду“) сусрећемо међу осуђеницима галиотима и једног који се представља да је написао повест о свом животу; то је Хинес од Пасамонта, лик који ће се јављати у више наврата у роману као епизодна фигура. Његова пикарска књига није довршена („Како ће да буде довршена“, пита се он, „кад ми ни живот још није довршен?"), а он са̂м је једна од фигура амбиваленције и превртљивости: кад Дон Кихот, у заблуди да спасава праведнике, буде ослободио галиоте, Хинес ће узвратити тако што ће опљачкати свог спасиоца. Уопште ће се тема спасавања ближњих у невољи - из хоризонта месијанства и Христа спаситеља, у кључу витешког, оружаног хришћанства, али и изван тог кључа, као тема спасења на земљи, понављања Христове жртве и намере у овом животу - развијати кроз више епизода у роману, тако да постаје 
једна од средишњих, а на извесну imitatio Christi, омиљену тему позног средњега века и њене ренесансне обнове под видом еразмовске devotio moderna, могло би упућивати и само арапско име „изворног хроничара“ Сид Амета Бененџелије (Сид Хамет Бененгели: „господин / који хвали Господа / син Јеванђеља“).

И док умножавање приповедачких фигура, од симболичког (конвенционалног) арапског хроничара, преко имагинарног маварског преводиоца, до реалног наратора који се тако скрива иза претходних и уклања из самог штива, утврђује илузију објективистичког приповедања, али и допушта окретање текста према себи у игри амбиваленција и дистанце, повећава волумен приповедања и гради мрежу различитих перспектива и регистара, дотле је главна фигура романа, Дон Кихот, и сама у највећој мери фигура амбиваленције. Као што је познато, Дон Кихот непрестано својом имагинацијом надодређује симболичко-конвенционално значење појава које сусреће. Али његова сањарска природа није резултат натуралне генезе, већ артефактичка, књишка: лудост Дон Кихота има извор у превеликој, преобимној, и у сваком значењу претераној лектири. Такође, и то је од не малог значаја, та лектира има своју поетику. Наиме, и други ликови Дон Кихота, посебно берберин и парох, односно војвода и војвоткиња или Сансон Караско у другом делу романа, радо се предају читању витешких и осталих романа; код Дон Кихота је лектира у спрези с поетиком миметичког разумевања књижевности, са херменеутиком имитације. Знамо колико је ова платоновска, метафизичка херменеутика владала старим добом и ренесансом: подражавање је било у исти мах основа за разумевање генезе фикције, као и за њену легитимацију, то јест ограничање. Овај проблем - колико текст одражава, опонаша или подражава друге текстове, односно природу, то јест да ли су људска субјективност и њене представе о себи, свету и својим способностима миметичке и на који начин - у својој суштини је теоријско-филозофски проблем: он особом скицира читаву једну епистемологију, као теорију сазнања, односно етику, као теорију понашања и владања. Дон Кихотово лудило учинак је лектире према чијим ефектима се јунак понаша миметички: он хоће да опонаша изван књига оно што је нашао у књигама. И док његова дела, понашање и догодовштине теку, из његовог угла, као што реалније приближавање фиктивноме, câм роман се према тој мимези понаша иронично: врхунац ироније на рачун миметичких интенција главног јунака можда је развијен у XXV поглављу кад Витез Тужнога Лика борави у Сијера Морени, где се предаје, лишен других искушења и пустоловина, „подражавању испаштања Белтенебросова“, то јест аскетизму 
које се и дословце изокреће наглавце, онако како се и Витез, наг и предат својој лудости, изокреће наглавце и надаље дуби на глави: „У томе и јесте тананост мога посла“, објашњава Дон Кихот свом пратиоцу,

Јер то да лутајући витез помери памећу што има повода, то нити је лепо ни што особито; али мајсторија је полудети без повода, па дати разумети својој дами: кад ово овако радим без повода, да шта бих тек чинио кад би повода било?

Тиме је повод, као тачка с које је разлог себе развио из потенцијалног у реално, престао да важи у пољу реалног: реално се сасвим сакрило иза имагинарног, умишљеног, фиктивног, које се са своје стране распрострло преко симболичког, преко симбола у ширем смислу као конвенције према којима знаци упућују на ствари тако да о томе сви имамо заједничке, опште представе око којих се разумемо. Овде разумевање тече у супротном правцу: субјект (Дон Кихот) разумева сходно својој машти, имагинацији, у сликама које са̂м гради, одлазећи на страну од конвенционалне симболике речи и знакова, општих представа и социјално прихватљивих значења. Тананост његовог посла састојала би се у замени симболичког имагинарним, у преношењу или метафоризацији тамо где то конвенције забрањују или спречавају: он је као фигура забуне и лудости, претеривања и транспозиције условљен могућностима језика да своје интерне регистре пренесе једне преко других, да своју унутрашњу разлику између симбола као конвенције и знака као слике протегне дотле да се између тих инстанци покидају везе, да саму разлику коју језик повлачи од ствари пребаци у разлику језика као ствари и језика као слике ствари. И док је главни јунак лик једне збрке или идентификације омогућене језиком, дотле је роман конфигурација разлика и њихових повлачења у разним правцима, иронизација на рачун претходних идентификација и забуна.

Употреба говора у његовој симболичкој функцији или регистру омогућава нам да значења разумемо конвенционално, преко општих представа, било да је њихова вредност дословна или пренесена: реч узета као симбол тада функционише по моделу античке тесере, знака сачињеног од две разломљене половине које се могу спојити изнова у целину неког смисла. На тој употреби почива разумљивост неке репрезентације и мање или више опште слагање око њене семантике. Међутим, кад се нека ознака узме, из ма ког то разлога било, као самостални ентитет, као иступи из регистра симбола, ослободи се представом коју заступа или репрезентацијом коју јој предаје заједничка конвенција, онда 
говорни елемент почиње да тражи своје ново, неконвенционално значење. Уколико му имагинација пружи слику која одступа од уобичајене представе и субјект у њој нађе смисао који му је потребан, заобилазећи питање о томе да ли је та слика конвенционално истинита или је она привид, фантазма, симулакрум, тада се разумевање одвија у хоризонту имагинарног регистра. Симболички и имагинарни регистар говора не разликују се по склопу, али се разликују по суштини: први истинитост (или вредност истине) знака везује за опште конвенције и представе, други за појединачне, сингуларне слике и случајеве. Тако су, у VIII поглављу романа, ветрењаче за Санча Панса јасне представе које ваља разумети као млинове, а ми, као читаоци, за које су ветрењаче речи или симболи у једној књизи, такође их разумемо као симболе које, иако их можда никад нисмо видели, лако допуњујемо оним на шта упућују њихова представљена значења. Међутим, за Дон Кихота уместо тих представа ветрењаче се осамостаљују као знакови чија значења сада долазе из света маште: он их тумачи као опасне дивове с којима ће повести бој. И док бисмо у првом случају, заједно са Санчом Пансом, заобишли ове направе, тек са Дон Кихотом стичемо шансу да их проверимо у реалности: то нису дивови, саме ствари као ствари по себи функционишу на свој начин, реалност сама не говори ни кроз представе ни кроз слике, реално „храмље“ у односу на симболичке или имагинарне регистре говора. Реално такође улази у говор, али је оно место празнине, неуспеха, ћутања око кога се говор организује и у симболичким и у имагинарним функцијама. Како би се код Дон Кихота сравниле ове две функције, биће увек изнова потребно да се непосредно суочи са стварима које говорна мрежа обавија било општим представама, било личним фантазмима, али које саме не говоре, већ напросто постоје, јесу - и за сваки говор остају загонетка.

Епизода битке с ветрењачама је једна од најпознатијих из читавог романа и скоро да је амблематска. И не само за роман о Дон Кихоту и за његов лик. Она је постала амблематска или симболичка за свако настојање, од жеље па до потхвата, да се учини нешто племенито, а против сувише тврде стварности, за племенитост која надилази и супротставља се реалностима, највише реалностима историје. „Борити се с ветрењачама“ постало је ознака за борбу против премоћних сила историје, која је оправдана јер је морална или револуционарна, етичка или превратничка, па макар сами непосредни резултати били мршави или никакви, пре утопијски него реални. Али из саме историје на коју би ово место у роману посредно упућивало стижу другачији знако- 
ви. Ветрењаче су биле техничка новотарија у Шпанији на крају XVI и на почетку XVII века. Дон Кихотов сукоб је сукоб с технологијом, сукоб старог доба са новим. Пре него револуционар, Дон Кихот из ове епизоде показује се више као реакционар, као представник старог времена, конзервативна фигура која не жели да прихвати нововековље, модерност. И више од тога: ако знамо да су ветрењаче пре свега изум који се из Холандије раширио по Европи и тако доспео до Шпаније, а сетимо се да су у та времена Холандија и Шпанија љути противници на морима, непријатељи због колонијалних амбиција у новооткривеним прекоокеанским земљама, епизода борбе с ветрењачама добија још један, ако не негативан а оно сумњив призвук. То све чини да се лик Дон Кихота у роману развија као амбивалентна, чак поливалентна фигура, да између саме романескне повести и историје света постоје тензије, дистанце, обрти и преокрети који обема странама отварају нова поља.

И док први део романа рачуна на то да ћемо читање усмеравати у правцу изједначавања текста и онога како јунак тумачи свет, други део романа, објављен десет година након првог дела, уноси читаву једну нову димензију у простор свога писма. Дон Кихот поново креће да тражи пустоловине, али је сада то промењени Дон Кихот. Још од епизоде у Сијера Морени он разлику која се испоставља између симболичког значења појава и имагинарне пројекције у његовом духу - и коју све чешће увиђа, чим се његове илузије распрше - оправдава постојањем тзв. злих волшебника, чаробњака или злодуха који га систематски варају, али чијој превари не може да измакне пре него што је на делу не провери. Поље реалног, оно на које у конвенционалној употреби језика упућује симболички регистар дискурса, кад речи или знаке уопште везујемо за неку ствар, за референт као еквивалент ознаке, а чему заправо приступамо прелазећи кроз имагинарно, с том разликом што у тзв. стандардној, редовној употреби говора имагинарно не стоји, као код Дон Кихота, на путу сравњивања симбола и реалности, већ се стапа са њима, овде опет остаје празно. Уместо онога што би била реалност, Дон Кихот види чаролију. Модерно доба, на чијем је почетку и Сервантесов роман, развијаће посебну технику експеримента као начина провере наших мисаоних, симболичких конструкција: ако постоји једна дискурсивна, теоријска конструкција о кретању звезда, на пример, техником експериментисања, провера, уз инструменте који се изналазе за ту технику, повећаваће се сагласност те концепције са оним сликама које нам се испостављају као слике стварности, света или космоса. Одређени прорачун биће плаузибилан уколико се огледом потврди као слика која одговара реалном. Модерно 
доба ће тако развијати своја сазнања у правцу истине као адеквације наших менталних, симболичких представа и ствари на које упућује; имагинација ће бити део технике прорачуна, уклапаће се у сравњивање симболичког и реалног и неће им стајати на путу. Донкихотовске фигуре, у којима би се имагинација истицала као препрека за овакво сравњивање, служиће за опомену на могућу лудост, на екстраваганцију маште, на одступање од истинитог, правог пута методског сазнања и понашања. Кад свега две деценија након Сервантесовог романа Рене Декарт буде писао свој Дискурс о методи (1636), он ће се, скоро непосредно, осврнути на „витешке екстраваганције“, имајући у виду оно што ће модерно раздобље назвати „донкихотеријом“, претеривањем имагинације на рачун методске употребе разума. Тако ће роман о Дон Кихоту, и уопште модерна имагинативна књижевност, заузети другу, негативну страну, страну наличја за модерни пројект научног, методског сазнања. И упркос томе што ће се на позадини „непоуздане“, „екстравагантне“, сликама и имагинацијом детерминисане области зване литература од те области непрестано отискивати и разлучивати област методски поузданог, научног сазнања, науке као такве, Декарт ће, у својству онога ко је положио темеље модерној научној епистемологији, у својим Медитацијама, крајњу, коначну извесност људског сазнања и субјекта оправдати позивањем на трансцендентну гаранцију: Бог, каже Декарт, не може ме варати у погледу тога да мислим у часу кад мислим и да стога јесам онда кад јесам. Такву, крајњу извесност у самоспознаји субјекта, гарантује неко ко је изван сваког хоризонта субјекта, па и сазнања као људског сазнања; уколико такве гаранције не би било, образлаже Декарт, неминовно бисмо пали у наручје неког „злог волшебника“, „злодуха“ (le malin génie), онако, управо у оно како Дон Кихот сматра да је запао кад доживи неуспех својих имагинарних пројекција. У модерном пројекту научног сазнања и овладавања светом литература ће играти улогу подсетника на могућност грешке, застрањивања маште, лутања субјективности; та ће улога бити на свој начин конститутивна, без обзира на одбијање научне модерности да је призна. И у мери у којој је Декарт оснивач модерне научне, епистемолошке парадигме, у тој је мери и Сервантес својим романом положио темеље за пројект књижевности као имагинативне делатности која нам о стварном говори преко слика, маште и илузије. Иако супротстављена један другом, та два пројекта су на свој начин нераздвојна.

Ако први део Дон Кихота ставља у средиште проблем читања као извора пометње за главног јунака - Дон Кихот чита витешке романе услед чега помери памећу - други део Дон Кихота 
ставља у средиште и ово читање и спис који је о томе читању био написан. Наиме, у другом делу сусрећемо бројне ликове који су већ читали први део романа, који већ „знају“ Дон Кихотове пустоловине и његов карактер јер су читали књиге о њему. Постоје барем два круга читања и списа: у првом је Дон Кихот и његова лектира; у другом је први круг, али и лектире оних који су већ читали први део. Трећи круг читања, који обухвата претходна два, састоји се, наравно, од нас који о свему томе читамо у укупном Сервантесовом роману. Ови кругови или хоризонти нису исти, иако се понекад потоњи слажу преко првих и прете да их затамне. Ствар се додатно компликује и тиме што је, пред појаву другог дела Сервантесовог романа, у јесен 1614. године објављен још један наставак, литерарно знатно слабији, Дон Кихотових авантура из пера извесног Авељанеде. Ко је тај настављач, то је остало загонетка све до данас. Сервантес даје штуре податке о могућем аутору овог неочекиваног наставка, одакле сазнајемо да би иза псеудонима стајао такође неки писац-војник, близак кругу око Лопе де Веге. Поједини новији истраживачи (Рикер де Мартин, на пример) сматрају да би писац тог наставка могао бити онај исти Хинес од Пасамонта кога је Сервантес представио у веома ироничном светлу у XXII глави првог дела свог романа. Уколико би та претпоставка била тачна - а поједини детаљи као да је могу потврдити - тада бисмо имали још један, нов обрт у игри илузије и истине, фикције и реалног: јунак, макар и епизодни, câм постаје аутор, књига се прелива преко свог руба како би се отворила за нове књиге. Ову ће могућност Сервантес на свој начин искористити: Дон Кихот из његовог романа повлачиће границу између себе и „лажног“ Дон Кихота Авељанединог, као разлику између стварног и фиктивног, иако су, у простору књига, обојица подједнако фиктивни ликови, фигуре имагинације. Могућност да се фикција сада ослони на фикцију, да књига живи даље тако што ће ослањати свој већ започети, али претходни живот, да се писање нових пустоловина и епизода ужлеби у читања која су већ обављена, да се, укратко, роман окрене према самом себи, та је могућност у другом делу из самог средишта романа доспела на површину. И док Дон Кихот у првом делу започиње као ренесансни текст који извире из амбиваленција симболичног и имагинарног, из двосмислености о томе шта је истина а шта фикција, у другом делу он се претвара у барокну уметност која се окреће према себи, како би описала око себе нове кругове.

Други део - објављен 1615. године, деценију после првог дела - зато ће донети нове фигуре аутора. Наиме, у другом делу ће они који одређују збивања бити ликови - попут војводе и 
војвоткиње и њиховог окружења, или попут лиценцијата Сансона Караска итд. - који су читаоци романа о Дон Кихоту: са̂м јунак се, заправо, креће кроз артефицијелни простор инсценација које су унапред спремљене за њега. Као у великој игри огледала, или у театру у којем једнако иступају двојници протагонисте, кретање Дон Кихотово биће извор нових забуна, утолико што је он једини лик који пак није читао роман о себи. Он, који је толико читао, сада не чита - и мада је његова ранија лектира одредила његову судбину, његова судбина сада зависи од једне нечитљивости чије је средиште у њему самоме. Ако је раније био фигура која имагинарно испоставља на рачун симболичког, при чему је реално остајало немо, нечитљиво, и бивало извор за његов неуспех, сада је он у очима других, својих читалаца који су ступили и сами на позорницу, како би наставили игру знакова и говора оформљеног првим делом романа, један симбол чија значења долазе из имагинације његових нових читалаца, а он са̂м стоји као једна врста реалног о које се ова нова игра симбола и имагинације слама. Он се суочава са властитим двојницима, он ће се на крају романа, у завршној глави другог дела, суочити са самим собом и својом смрћу. Издужен његов лик биће знак питања који је своју сенку бацио на читав свет описан у роману, али и на свет изван романа, у игри књижевности са оним што је у њој читљиво - а то значи разумљиво у општим представама језика - и са оним што је нечитљиво - у разликама које говор крије, понавља, и подстиче онда кад покушамо да га заменимо за свет. Читајући свет како би потврдио књиге, Дон Кихот је сведочанство о томе да између света и књига, у језику који треба да нам омогући свако читање, постоје раздори које не можемо прескочити, мреже у којима смо већ унапред уловљени, чим покушамо да њима уловимо ствари, разлике које су у исти мах услови могућности да се разумемо и услови немогућности да то учинимо једном за свагда. Сервантесов роман настаје из овог простора разлике, као први модерни роман о расцепу субјекта између језика и света, разума и маште, културе и историје.

У дну тог расцепа стоји и рез и повезаност читања и нечитљивости. Ако се вратимо на почетак, на епизоду у којој нам писац, односно његов главни приповедач, прича како је настао роман који читамо, налазимо да је у дну генезе једна нечитљивост. Наиме, на пијаци у Толеду је приповедач налетео на неке папире, а како воли да чита, „па макар то биле и уличне хартије“, њега је то до те мере заинтересовало да је купио свежањ који се нудио. Међутим, те су хартије биле испуњене арапским писменима, које приповедач не уме да чита. Све надаље је, из 
ове почетне нечитљивости, из нечитљивог темеља на којем ће се изградити роман, ствар преноса, превода, метафоре. Прво ће неки дечак с пијаце пренети, превести, учинити читљивим тај темељ; онда ће се то поље изворне нечитљивости одредити и именом извесног Бененџелије, Арапина. Па ће се и главном јунаку повести, Кехади преименованом и самопреименованом у Дон Кихота, одредити као кључна особина нечитљивост унутар претераног читања - он ће, наиме, читати витешке романе у тој мери, с таквим заносом, и у толикој количини да ће му они остати сасвим нечитљиви као романи, односно као фикције или измишљотине о ликовима и догодовштинама. Ако је Серватесов роман и стварни почетак, и узор, парадигма модерног романа, онда модерност почива на једној нечитљивости, односно и на фикцији о нечитљивости као на извору све друге фикције, а не само на томе да једно, потоње дело чита раније дело и тако гради традицију. Традиција је пренос, превод, преношење једних дела у друге; она је предаја истог различитом, превод једних дискурсивних регистара и слојева у друге. И увек у оном преданом остаје неки удео, траг, или слој нечитљивог, како би се, око тог празног места за читање створило ново дело.

Борхес ће то искористити у својој познатој причи „Пјер Менар, аутор Дон Кихота“ (1939). Такође под маском коју је већ користио Сервантес, Борхес говори гласом свог приповедача који је нека врста историчара, квалификованог читаоца, који ће причати о другом аутору, књижевнику. Тај књижевник, Менар, наумио је - врло донкихотски - поново да напише роман о Витезу тужног лика, и да дословно (verbalmente) испише оно што је већ било исписано и објављено почетком XVII века. Менаров текст ће дословно бити једнак Сервантесовом, потпуно идентичан изворнику, али, каже Борхесова прича, „тако рећи бескрајно богатији“. Менар неће то учинити преписивањем, већ без гледања у изворник, властитом имагинацијом, ослоњеном на тек далеко, мутно сећање и читање Сервантесовог романа. Нећу улазити у бројне литерарне и металитерарне алузије које врве у Борхесовом тексту, нити у детаље приче, осим у неколико „ситница“ које су измицале пажњи читалаца, критичара и тумача Борхесове парадоксалне замисли о „Пјеру Менару, аутору Дон Кихота“. Наиме, Борхес нам, као успут, негде при крају приповедања, каже - или нам то каже његов приповедач - да је Менар, не успевши да оконча свој подухват, иза себе оставио

дело које се састоји од поглавља деветог и тридесет осмог првог дела Дон Кихота и једног одломка двадесет и другог поглавља (esa 
obra... conste de los capitulos noveno y trigésimo octavo de la primera parte del Don Quijote y de un fragmento del capitulo veintidós).

Та поглавља пак у Сервантесовом Дон Кихоту, сама су захваћена мотивом нечитљивости. Поглавље двадесет и друго је оно у ком Дон Кихот ослобађа осуђенике, међу којима има и злочинаца, које све сматра „несрећницима које су против њихове воље водили тамо куд нису желели да иду“; племенитост Витеза Тужнога Лика разоткрива се као саучешће или барем небрига о злочинствима, све услед тога што није како ваља прочитао намере зликоваца и читав догађај њиховог одвођења на заслужену робију. Будући да их није како ваља прочитао, те епизодне ликове и саму ситуацију, Дон Кихот од племенитог витеза постаје ослобађањем зликоваца - властита супротност, и са̂м зликовац. Поглавље тридесет и осмо представља „знамениту беседу коју је Дон Кихот одржао о оружју и о науци“. Оружје је у свету Сервантесовог романа средство последње, коначне одлуке о животу и смрти, истини и неистини, познатом и непознатом, а „наука“ - у роману је означена као las letras, што су, осим знања, и „слова“, „књиге“, „писмена“, „написано“, односно литература у свим значењима тог израза - јесте нешто што сада лоше пролази у Дон Кихотовој беседи. „Нека ми не излазе на очи они који веле да књиге имају предност над оружјем, јер ћу им казати, па били они ко им драго, да не знају шта говоре“, каже Витез. Он који је пореметио памећу услед књига, претераног и наопаког читања, он који је и са̂м једна књишка фигура која постоји у фикцији једног романа, окренут је сада против књига, читања, слова, фикције у фикцији. Како читати тај парадокс? У првом реду као нечитљивост на коју Дон Кихот ослања свој аргумент, нечитљивост која истиче своју супротност, наводну предност читљивости оружја.

Коначно, девета глава коју је „поново написао“ Менар оно је поглавље из Сервантесовог романа у ком се говори о генези приче, односно и нечитљивости изворника купљеног на пијаци у Толеду.

Борхесова прича није само чувени пример „постмодернизма“ у литератури, већ нам је важна утолико што нам може помоћи да кажемо нешто о читавом том добу ренесансе, односно почецима модерног доба из угла мотива читања и нечитљивог, и то на више начина, или у више перспектива. Најпре, може се рећи да је западни средњи век, теолошко доба европске историје, учинило лектиру антике - нарочито оне старогрчке, а већим делом и римске - нечитљивом, јер ју потиснуло, каткад и одбацило, као наслеђе једног паганског света, а да је ренесанса - „обнова“, односно „препород“ - покренута као покушај да се то нечитљиво 
опет прочита. И не само прочита, већ да се у оном што је претходна ера учинила нечитљивим пронађу увиди за читање - схватање, разумевање, поступање - властите савремености. И да се то опет прочитано испише за нова читања.

Потом, у том новом, обновљеном, препорађајућем читању антике појављује се, осамостаљује до извесне мере, нова фигура човека. Чине то „хуманисти“ који ће бити, дословно, читаоци тзв. световних списа, световне, а не више само теолошке литературе. Кад буде касније европско просветитељство с краја XVIII и нарочито током XIX века створило данашњу слику о ренесанси као „обнови антике“ - а реч је о обнови занимања за антику, што није исто, односно о занимању за савременост које је текло и преко обнове занимања за стара времена - створиће се и представа о „хуманизму“ из ренесансног доба као човекољубљу, и утолико ће нам се заклонити - и учинити делимично нечитљивим - значење ренесансног хуманизма као нове врсте читања старих списа. Једна нечитљивост ће створити другачије читање, а ово поново створити или отворити нову нечитљивост. Није реч о „дијалектици“ читања и нечитљивости, у којој би се, као у свакој дијалектичкој прогесији, једно сменило „вишим“ стањем или ступњем, при чему би та дијалектика свакако морала бити вођена повећавањем или „уздизањем“ читања као пресудније вредности у историји културе и света. Не, у мери у којој су читљивост и читање као операција шире него што је то срицање слова у речи, а речи у реченице, неопходне за културу, утолико је нечитљивост - ова о којој пишемо, и која је шира од тзв. неписмености или непознавања текста - неопходна стварању. Стварање и култура нису синоними, култура се - можда оном својом важном страном коју су открили Ниче, а онда и Фројд, па и други иза њих - као скуп етаблираних вредности може веома снажно супротставити стварању.

Ренесанса је настала и из једне нечитљивости, не само услед наслага средњовековне теолошке парадигме мишљења и говорења, и не само услед теолошког одбацивања паганске антике, већ и услед тога што је сама, и то код својих највећих аутора, „погрешно“ читала и своје доба, и антику. „Погрешка“ те врсте није случајна, односно „нечитљивост“ ренесансе је била део њеног пројекта или програма, у широким распонима нове космологије из које је читала и звезде на начин астрологије, и новог материјализма који је читала и магијски, мантички, гатањем по херметичким или мистичким учењима, и нове врсте мишљења које је трансценденцију с неба свукло на земљу, стварајући нове 
или обновљене врсте метафизике сходно занимању за тада другачија читања Платона и Аристотела, па и нове врсте певања, односно литературе, која је код Дантеа читала свој субјект још увек у амалгаму теологије и антике, хришћанства и паганства, а онда, преко Бокача, све до Раблеа, Монтења и Сервантеса, код којих се читању - и писању - модерни свет излаже као још једна нечитљивост пред којом не треба стати, већ јој се - управо средствима писања, оруђима стварања - ваља сучелице поставити у промењеном разумевању тог света. Док Кихот је, тако, фигура која је и нечитљива, јер припада једном старом свету - он са̂м овако како је описан код Сервантеса у роману пре је средњовековна фигура наоружаног хришћанина, витеза који још верује у теолошко-етичке вредности и идеју спасења - и фигура за ново доба, јер ће се сваки даљи лик који се буде упустио у модерно доба, које траје и дан данас, са вером да може свој свет прочитати до краја - испоставити као лик једне или друге, овакве или онакве „донкихотерије“. Чак и наше читање овог ренесансног романа припада таквој врсти „донкихотерије“, не само сервантесовске, већ и оне „менаровске“, борхесовске, ако само поверујемо да смо ренесансу као доба, једног од њених водећих аутора - успели да прочитамо до краја. Све до чега смо, надамо се, дошли - представља само наш наговор на нова читања с овим аутором који је, у својој читљивости и својој нечитљивости, још увек један од најважнијих извора нашег света, наше модерности, па стога и наше савремености.

\section{Лumepamypa}

Милић, Н. (2002). Модерно схватање књижевности. Београд: Завод за уџбенике и наставна средства.

Сервантес, М. де (1895). Велеумни племић Дон Кихот од Манче, књ. 1-4. Београд: Задужбина Илије М. Коларца.

*

Cervantes, M. de (1998). Don Quijote de la Mancha, vols. I-II. Francisco Rico (edición dirigida por). Barcelona: Instituto Servantes.

Ascunce Arrieta, J. Á. (1997). Los quijotes del Quijote: Historia de una aventura creativa. Kassel: Reichenberger.

Borges, J. L. (1997): Ficciones, Madrid: Alianza.

Dobbs, R. (ed) (2006). Don Quixote and the History of the Novel. Cambridge: Cambridge University Press. 
Johnson, C.B (2006). Don Quijote Across Four Centuries - 1605-2005. New York: Routledge.

Ortega y Gasset, J. (1914). Meditaciones del Quijote. Madrid: Residencia de Estudiantes.

Sacerio-Gari, E. (1980). Towards Pierre Menard. Modern Language Notes, 95, 2, 400-471.

Salazar Rincon, J. (1986). El mundo social del Quijote. Madrid: Gredos.

\section{Novica Milić}

Faculty of Media and Communications, Singidunum University, Belgrade

\section{Don Quixote and Literature}

\section{- Summary -}

The present essay makes an effort to see Cervantes' novel Don Quixote within the perspective of the birth of the modern novel as a literary genre - a genre that had existed before Cervantes but only with the modern ironic, historic and poetic experience of the Renaissance epoch became what it would be in the centuries to come - the most accepted and the most useful form of reflecting upon the world and life. Using irony, the novel about Don Quixote distances itself from both its main hero and earlier literature, as well as from earlier medieval times and culture. Historically, the novel deals with the past and the present, in a broad and new perspective unknown in previous epics. We particularly paid attention to the change between the two parts of the novel - the first one from 1605 and the second part from 1615 - when the hero Don Quixote, who had read the world from its lectures of chivalric novels, is now being read by other characters in the novel, since in the meantime they read the first part and the fake sequel of the unknown author named Avellaneda. Now he does not read his own story and becomes a figure of certain unreadability, which gives rise to many ambiguities and polysemy in the novel. This new topic of unreadability is of crucial importance for the overall meaning of Cervantes' novel and it could be seen in detail in the light of Jorge Luis Borges's story „Pierre Menard, Author of Don Quixote“.

Keywords: Cervantes, Don Quixote, Renaissance literature, modern novel, irony, readability, unreadability, Borges. 